\title{
ENVIRONMENTAL IMPACTS OF WOOD PALLETS: A SYSTEMATIC REVIEW
}

\author{
Karla Juliana F. de Souza ${ }^{a}$, Lilian Lefol N. Guarieiro ${ }^{a}$, Jeancarlo P. dos Anjos ${ }^{a}$ \\ aMPDS, Centro Universitário SENAI CIMATEC, Brazil
}

\begin{abstract}
This work had analyzed the contribution of scientific studies developed in regard to the environmental impacts of using wood pallets. This analysis utilized a systematic review from the available literature found on four important databases: Scielo, Science Direct, Web of Knowledge and CAPES. There is still not a representative number of studies performed concerning the environmental impacts of wood pallets and only 5 countries stand out as key players: USA, Italy, India, Iran and the Netherlands. It was demonstrated that there exist prospects which could be applied to mitigate the environment and cost impacts of wood pallets, regarding alternative materials, logistical strategies and practices of maintenance, re-use and recycling.
\end{abstract}

Keywords: Wood; Pallet; Environmental impacts; Sustainability.

\section{IMPACTOS AMBIENTAIS DOS PALLETS DE MADEIRA: UMA REVISÃO SISTEMÁTICA}

Resumo: Este trabalho analisou a contribuição de estudos científicos desenvolvidos sobre os impactos ambientais dos pallets de madeira. Foi feita uma revisão sistemática da literatura disponível em quatro importantes bancos de dados: Scielo, Science Direct, Web of Knowledge e CAPES. Ainda não existe um número representativo de estudos desenvolvidos sobre os impactos ambientais dos pallets de madeira e apenas 5 países se destacam como principais atuantes: Estados Unidos, Itália, Índia, Iran e Holanda. Foram identificadas oportunidades que podem ser aplicadas para mitigar o impacto ambiental e de custos dos pallets de madeira, no que diz respeito a materiais alternativos, estratégias logísticas e práticas de manutenção, reuso e reciclagem.

Palavras-chave: Madeira; Pallet; Impactos ambientais; Sustentabilidade. 


\section{INTRODUCTION}

According to the Global Footprint Network (GFN) [1], since the 1970's, Earth has consumed more natural resources than the planet is able to regenerate, and currently Earth is meeting a level of 1.75 of consumption, almost double of the regeneration limit.

This is a critical issue, which can put at risk the future of our population and one of the key contributors relates to the accelerated deforestation process. According to INPE (Brazil National Institute of Space Research) [2], between August 2018 and July 2019, the deforestation of the Amazon increased by $30 \%$ with almost $10,000 \mathrm{~km}^{2}$ deforested, what is equivalent to 1.4 million soccer fields.

As stated by ONU (Unit Nations Organization) [3], deforestation is the second biggest root cause of climate change, while the burning of fossil fuels is the leading source. Forests can absorb around 2 billion tons of $\mathrm{CO}_{2}$ per year and their preservation can help to mitigate climate changes. In this context, Kočí (2019) [4] brought to our attention that over $80 \%$ of all world trade is currently carried out using pallets and $90 \%$ of those pallets are made from wood, as clarified by Carrano, Thorn and Woltag (2014) [5].

According to the greenestpost, 1.7 billion wood pallets are produced annually in Asia [6]. The reason why wood pallets are so predominant is due to their low cost, adaptability and ease of disposal. Based on that, we can conclude that the use of wood pallets worldwide significantly contributes to the high level of consumption of natural resources.

Assuming this situation of substantial resource consumption, adding to it human population growth, among other critical global issues, the United Nations raised the 17 sustainable goals in 2015, in order to contribute to a better world and pursue a sustainable development for all. The following sustainable objectives are the ones which are more correlated to this study:

- Goal \#13 - Climate action: actions to combat the climate change and its impacts;

- Goal \#15 - Life on land: protect, restore and promote sustainable use of terrestrial ecosystems, sustainably manage forests, combat desertification, and halt and reverse land degradation and halt biodiversity loss [7].

Overall, the aim of this work was to perform a systematic review of the use of wood pallets and their impacts, reinforce the relevance of this subject, as well as to encourage people and companies to look for sustainable practices for business.

\section{METHODOLOGY}

The development of this study considered the following key steps, in the search for information on the use of wood pallets: (i) definition of the object of study; (ii) identification of databases to be consulted; (iii) papers categorized according to the 
field of knowledge; (iv) assessment of the key elements found in the papers; and (v) a summary of main findings and research outcomes.

Regarding the database, 4 different websites were used during the development of this research: Scielo (www.scielo.org), Science Direct (www.sciencedirect.com), Web of Knowledge (www.webofknowledge.com) and CAPES (www.periodicos.capes.gov.br). Two sentences were applied as keywords, during the research process: "Wood Pallets" and "Wood Pallets Sustainability".

The criteria used for filtering the research results was to evaluate the scientific paper associated to wood pallets written after 2006, considering an economic and environmental perspective.

An initial evaluation conducted on the title of the papers found was in order to select only those linked to the topic in question. After that, all the repeated articles were excluded from the list. The following step consisted in reading each of the abstracts to select only those which were the most correlated to this object of study, resulting in 24 articles for this systematic review (Table 1), which results will be discussed in the next section.

Table 1. Number of papers selected by database searched

\begin{tabular}{|c|c|c|}
\hline Database & $\begin{array}{l}\text { Selected Papers } \\
\text { (w/ repetition) }\end{array}$ & $\begin{array}{c}\text { Selected Papers } \\
\text { (w/o repetition) }\end{array}$ \\
\hline Scielo & 2 & 2 \\
\hline Science Direct & 19 & 18 \\
\hline Web of Knowledge & 7 & 4 \\
\hline CAPES & 3 & 0 \\
\hline Total & 31 & 24 \\
\hline
\end{tabular}

\section{RESULTS AND DISCUSSION}

Based on the 24 selected papers, we identify that the interest in regard to the impacts of wood pallet usage has significantly increased after 2014, since we observed $79 \%$ of publications occurred between 2014 and 2020 (Figure 1).

Figure 1. Publications over time about the impacts of wood pallet usage 


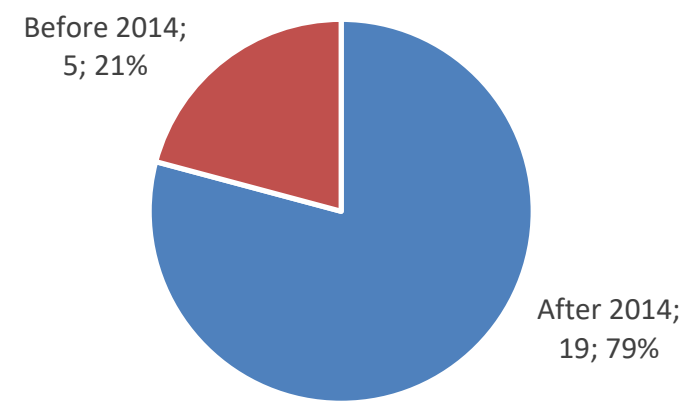

Among the 72 authors involved on the development of these 24 articles, 5 authors stand out, as shown in Figure 2. They had worked together and mainly focused on the carbon emission impacts of wood pallets.

Figure 2. Main authors who have published on wooden pallets

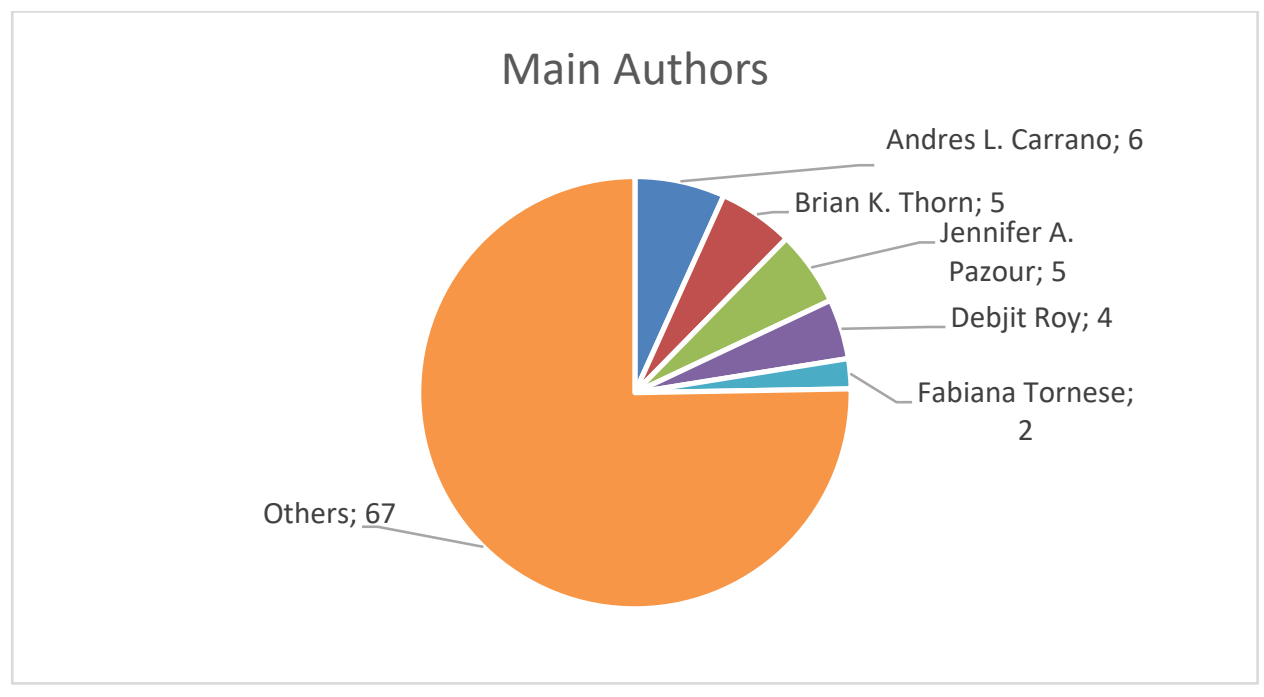

During the research, the papers were classified according to the field of knowledge in which they explored. Thus, the most prominent fields of knowledge in the 24 selected papers are shown in Figure 3.

Figure 3. Main fields of knowledge explored in selected papers 


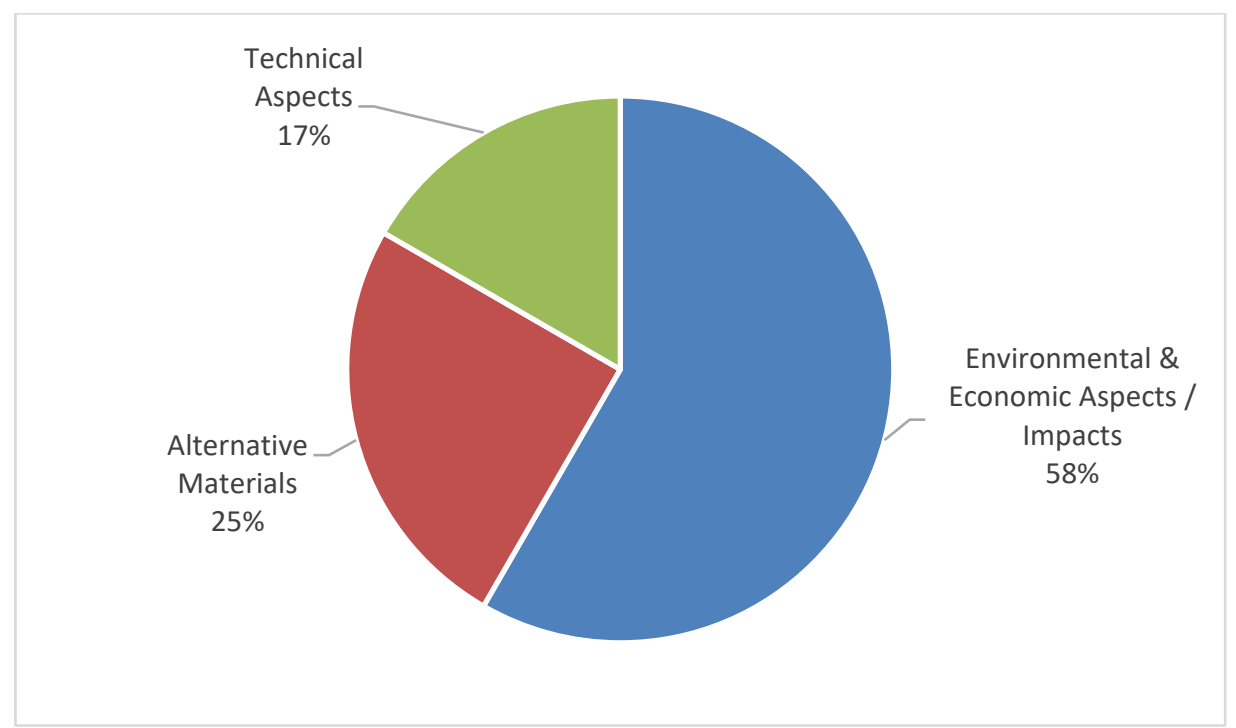

Furthermore, the analysis demonstrates that 5 countries are involved in most of the publications, participating in $58 \%$ of them: USA, India, Italy, Iran and the Netherlands. It is notable that the USA established a partnership with India, Italy and Iran, and the cooperation among those countries were responsible for $25 \%$ of the total publications. In addition, the predominance of the USA involvement in these studies is quite clear, since the country participated in $38 \%$ of the total publications (Figure 4 ).

Figure 4. Main countries that published on wood pallets

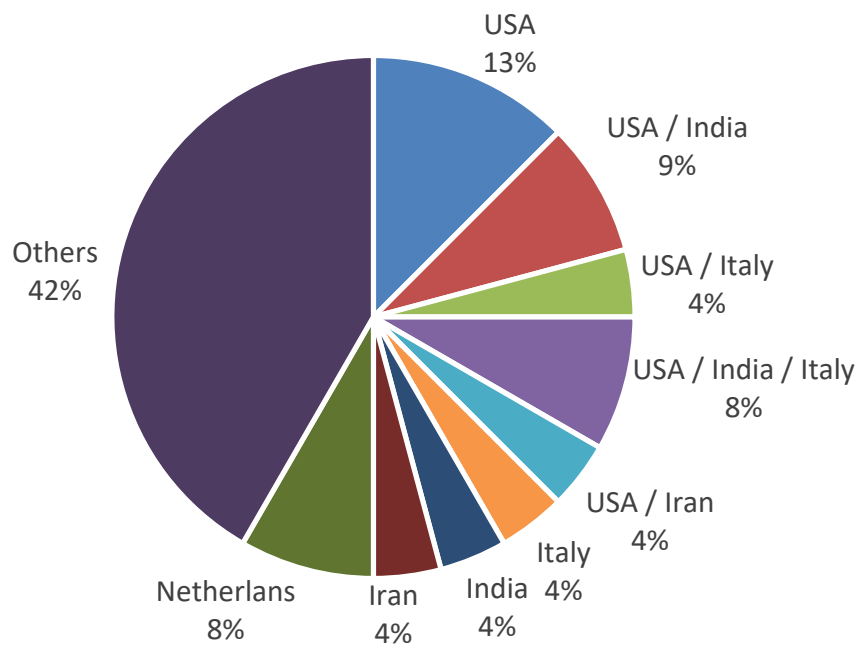

Figure 5 illustrates that North America, Europe and Asia focuses studies concerned with wood pallet impacts. It was observed that there was no participation of any country located in South America, Africa and Antarctica.

Figure 5. Distribution of publications on the impacts of using wooden pallets, by continent 


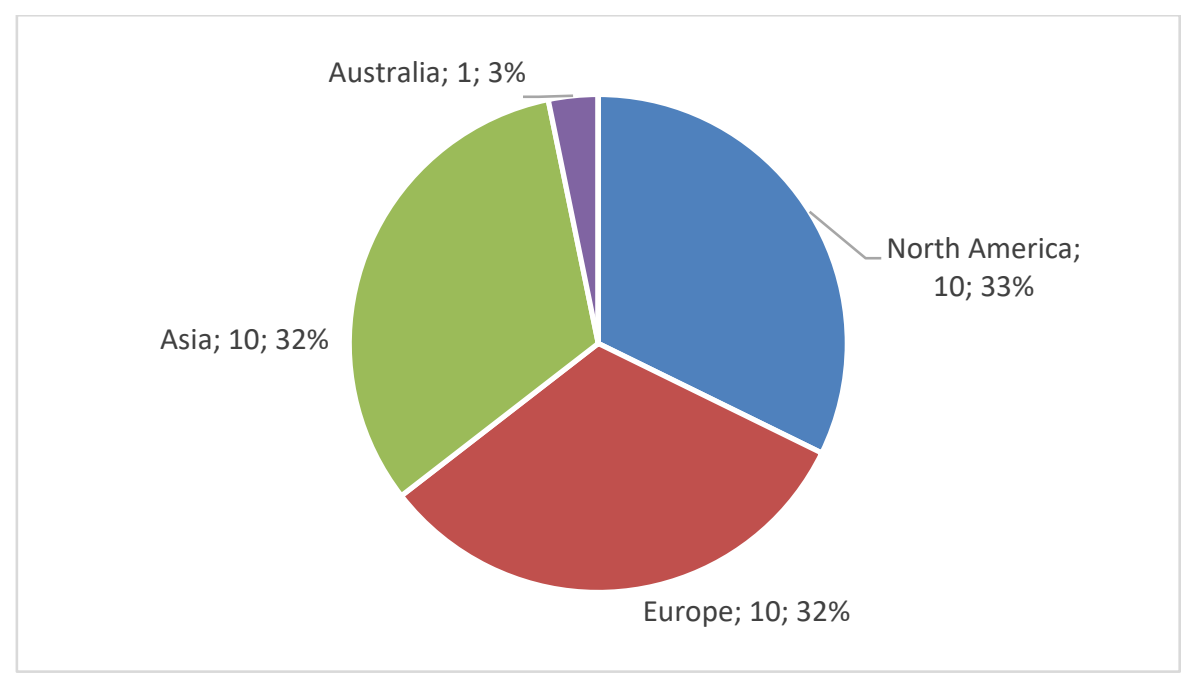

Additionally, we note the themes in research on wooden pallets, such as economic and environmental impacts, alternative materials for pallets and pallet technical matters have been well explored.

Most of the articles (14 from 24) related to the economic and environmental impacts of wood pallets. In general, we can summarize their object of study as follows:

- Carbon footprint: the conversion factor of raw material into pallets Pacheco et al. (2015) [8]; the comparison of potential environmental impacts from wood pallets versus plastic pallets - Kočí (2019) [4]; the benefits of recycling for carbon emission mitigation - $\mathrm{Ng}$ et al. (2014) [9]; carbon equivalent emissions associated with pallet remanufacturing operations and across all phases of the pallet life cycle - Tornese et al. (2016) [10].

- Logistic strategy influence on wood pallet environmental impact: wood pallet reverse logistics - Tornese et al. (2019) [11]; lifecycle of wood pallets as single-use expendable, reusable buy/sell and reusable leased pool - Carrano et al. (2014) [12]; the combination of the pooler's management strategies with different retailer network configurations and the business of pallet management by analyzing the transport operations - Accorsi et al. (2019) [13].

The main findings from papers focused on carbon footprint impact indicates that the wood pallets are more environmentally friendly than plastic ones, although their lifecycle is shorter. Furthermore, it was estimated by Koči (2019) [4], that $1 \mathrm{~m}^{3}$ of wood can produce 22.6 wood pallets and the number of the usage cycles of the wood pallets is approximately 15 , versus 100 cycles from the plastic pallets.

The research shows the key points considered as offenders for environmental impacts are: the deforestation process, the electricity consumption during the pallet production process, the pallet load capacity during the transportation, since the consumption of gas emissions increases according to the weight of the cargo transported, and the wood pallet disposal methods. In addition, it was demonstrated that the recycling of wood waste and preemptive pallet practices can help to mitigate carbon emissions. 
On papers developed based on pallet logistical matters, the results displayed the crossdocking strategy can reduce the costs and emissions of new pallets. Also, the cost of leased pallet pooling programs is more attractive than the buy/sell programs (can vary based on the supply chain) and the combination of pallet management strategies, as pooling and buy/sell, can be an attractive option to reduce cost as well as the vehicle travel distance, resulting in the reduction of carbon emissions.

Some investigations conducted were to optimize the current wood pallet materials, or to replace them with alternative ones. Certain studies focused on different materials, such as: rubber - Gangadhara et al. (2016) [14]; wood composites with rice straw, rice husk and paper sludge - Kim, JoongKim and ChulParkc (2009) [15]; composites of recycled corrugated paperboard and plywood - Masood and Rizvi (2005) [16]; and pallets made from wood filler-recycled polypropylene (WF-RPP) composite - Khoo et al. (2008) [17].

Overall, the analysis shows that there are alternatives which could be considered to manufacture wood pallets, still meeting material properties required for functionality, however further improvements would be necessary from a cost and manufacturing standpoint, so that these options could be disseminated.

Regarding the papers concentrated in the technical matters of wood or wood pallets, they have essentially focused on: how to perform pallet design optimizations; the recycling potential of wood waste into wood-wool/cement composite; the characterization of wood waste, according to its source, type and quality grade. The results indicate that the proposed design change optimization can meet the basic pallet targets (mass and strength) and that the wood pallet can be considered for woodwool/cement composite production (WWCB) due to its structure, which is similar to the spruce used to manufacture the WWCB - Berger, Gauvin and Brouwers (2020) [18].

\section{CONCLUSION}

This work demonstrates that, despite the relevance of this theme, there is still not a representative number of studies performed about wood pallet impacts on the environment, and there are only a few initiatives focused on pursuing green material alternatives. We can clearly see that the interest around this subject has started increasing recently, after 2014, and moreover only 5 countries have led a significant portion of these studies.

It was shown that several possibilities could be applied in order to mitigate the environment and cost impact of wood pallets, linked to pallet alternative materials, logistical strategies, recycling, re-use, preemptive practices, among others. All of them can play an important role in the contribution to carbon footprint reduction and climate change improvement.

In this sense, there is a necessity to increase the number of research and investigations in order to explore further opportunities and give more relevance to this subject, with the purpose to elevate the knowledge and further spread sustainable practices within the academic, business and industrial fields. 


\section{REFERENCES}

${ }^{1}$ Global Footprint Network (GFN). Déficit de recursos naturais. Availabe at: $<$ https://www.footprintnetwork.org>. Access on: January $15^{\text {th }}, 2020$.

2Instituto Nacional de Pesquisas Espaciais (INPE). Desmatamento na Amazônia. Available at: <http://www.inpe.br/>. Access on: November 19th 2019.

${ }^{3}$ Unit Nations Organization (ONU). Desmatamento é $2^{\mathrm{a}}$ maior causa das mudanças climáticas. Available at: <www.nacoesunidas.org>. Access on: January $15^{\text {th }}, 2020$.

${ }^{4} \mathrm{KOČI}, \mathrm{V}$. Comparison of environmental impacts between wood and plastic transport pallets. Czech Republic: Science of the Total Environment, vol 686, 2019.

${ }^{5}$ CARRANO, A.L.; THORN, B.K.; WOLTAG, H. Characterizing the Carbon Footprint of Wood Pallet Logistics. USA: Forest Products Journal, 2014.

${ }^{6}$ The Greenest Post. Pallets Biodegradáveis. Available at: $<w w w$. thegreenestpost.com>. Access on: July 25th 2020.

${ }^{7}$ The United Nations. 17 goals to transform the world for persons with disabilities. Available at: <www.un.org>. Access on: November 22 ${ }^{\text {nd }}, 2019$.

${ }^{8} \mathrm{PACHECO}$, A. et al. Conversion factor of forest products in sawmilling of pallets in Durango. Mexico: Rev. mexicana de ciencias forestales, vol.6 no.30, 2015.

${ }^{9} \mathrm{NG}, \mathrm{R}$. et al. Avoided impact quantification from recycling of wood waste in Singapore: an assessment of pallet made from technical wood versus virgin softwood. Singapore: Journal of Cleaner Production, vol 65, 2014.

${ }^{10}$ TORNESE, F. et al. Carbon footprint analysis of pallet remanufacturing. Italy: Journal of Cleaner Production, vol 126, 2016.

${ }^{11}$ TORNESE, F. et al. Environmental and economic impacts of preemptive remanufacturing policies for block and stringer pallets. Italy: Journal of Cleaner Production, vol 235, 2019.

${ }^{12}$ CARRANO, A. et al. Selection of pallet management strategies based on carbon emissions impact. USA: Int. J. Production Economics, vol 164, 2014. 
${ }^{13} \mathrm{ACCORSI}, \mathrm{R}$. et al. Environmental Impacts of Reusable Transport Items: A Case Study of Pallet Pooling in a Retailer Supply Chain. Italy: Sustainability, vol 11, 2019.

${ }^{14}$ GANGADHARA, V. et al. Design and Analysis of Rubber Pallet for Industrial Application. India: Materials Today Proceedings, vol 4, 2016.

${ }^{15} \mathrm{KIM}$, S.; JOONGKIM, H.; CHULPARKC, J. Application of recycled paper sludge and biomass materials in manufacture of green composite pallet. Republic of Korea: Resources, Conversation and Recycling, vol 53, 2009.

${ }^{16} \mathrm{MASOOD}, \mathrm{S} . \mathrm{H}$.; RIZVI, S. H. An investigation of pallet design using alternative materials for cold room applications. England: Int J Adv Manuf Technol, vol 29, 2005.

${ }^{17} \mathrm{KHOO}, \mathrm{T}$. et al. Wood Filler-recycled Polypropylene (WF-RPP) Composite Pallet: Study of Fastening Method. Malaysia: Journal of Reinforced Plastics and Composites, vol. 27, 2008.

${ }^{18}$ BERGER, I.F.; GAUVIN, F.; BROUWERS, H. J. H. The recycling potential of wood waste into wood-wool/cement composite. Netherlands: Construction and Building Materials, vol. 260, 2020. 